\title{
Polymer Composites Based on Plasticized PVC and Vulcanized Nitrile Rubber Waste Powder for Irrigation Pipes
}

\author{
Maria Daniela Stelescu \\ National R\&D Institute for Textile and Leather, Leather and Footwear Research Institute, 93 Ion Minulescu Street, \\ 031215 Bucharest, Romania \\ Correspondence should be addressed to Maria Daniela Stelescu; mstelescu@yahoo.com
}

Received 19 June 2013; Accepted 18 July 2013

Academic Editors: V. Contini, Y. X. Gan, and V. Ji

Copyright (C) 2013 Maria Daniela Stelescu. This is an open access article distributed under the Creative Commons Attribution License, which permits unrestricted use, distribution, and reproduction in any medium, provided the original work is properly cited.

\begin{abstract}
The paper presents the technique of production and characterization of polymer composites based on plasticized PVC and rubber powder from vulcanized nitrile rubber waste. The new polymer composites have lower hardness, higher elongation at break, a better tensile strength, and better ozone resistance, and the blend suitable for irrigations pipes for agricultural use was selected. The selected polymer composites have a good behavior under accelerated aging, repeated flexion at room temperature and at low temperature $\left(-20^{\circ} \mathrm{C}\right)$, a very good behavior for immersion in water, concentrated acid and basis, animal fat, soya, and sun flower oil, proving their suitability for gaskets, hoses, protection equipment, rubber footwear, and so forth. The resulted thermoplastic polymer composites can be processed by injection, extrusion, and compression molding.
\end{abstract}

\section{Introduction}

An efficient reclaiming of wastes resulted from the manufacture of mechanical rubber goods can be achieved by their use in producing composite thermoplastic elastomer materials $[1,2]$. These composites can be used as thermoplastic material substitutes. Such substitutions can result in lower costs because of savings in thermoplastic materials while enabling the industrial rubber wastes to be reclaimed. Furthermore, the manufacture of such materials yields no wastes because of the spews and refuses being recycled. Composite materials based on thermoplastic and rubber powder are produced by mixing a dispersed elastic filler and a thermoplastic in a melt at a temperature above the melting point of the thermoplastic matrix on extruder-granulator, in Brabender plasticorder or on electrically heated roller mill. These materials are processed/moulded by a technique similar to those used in pro- cessing plastics and rubber blends (pressing, injection, extruded, etc.) [1-7].

The paper presents our work for producing polymer composites based on plasticized PVC and rubber powder from vulcanized nitrile rubber (NBR) waste and testing their characteristics. It deals with fitting the material characteristics in the standards for materials used for irrigation pipes.
Poly (vinyl chloride) (PVC) is a versatile polymer, used in flexible, semirigid, and rigid forms. In worldwide plastic production, it is second only to polyolefins. The rapid expansion and consumption of PVC is due to lower cost, greater availability, good mechanical properties, and diversity of its properties $[8,9]$. One of the most prominent needs for PVC in application end use is permanent plasticization. A very important and commercially significant blend is that of NBR and PVC. NBR acts as a permanent plasticizer for PVC, and at the same time PVC improves the ozone, thermal ageing, and chemical resistance of NBR. The presence of PVC improves aging resistance of NBR as both PVC and NBR are polar, and blending NBR with PVC increases the compatibility [10, 11].

Regarding this aspect, composites based on PVC/vulcanized NBR rubber powder do not need any compatibility agents in order to improve their characteristics.

\section{Experimental}

2.1. Materials. Materials used to obtain the polymer composites based on plasticized polyvinyl chloride and vulcanized nitrile rubber powder are as follows: (1) plasticized PVC prepared from PVC with a $64 \mathrm{~K}$-wert value (moisture and 
TABLE 1: Rubber powder characteristics.

\begin{tabular}{lcc}
\hline Reference number & Characteristic & Value \\
\hline$[1]$ & Acetone extract, \% & 23.86 \\
{$[2]$} & Ash, \% & 19.61 \\
{$[3]$} & $\mathrm{HCl}$ insoluble matter, \% & 8.85 \\
\hline
\end{tabular}

volatile $0.2 \%$, absorption of plasticizer DOP 100\%), dioctyl phthalate (DOP) (density $0.984 \mathrm{~g} / \mathrm{cm}^{3}, \mathrm{pH} 7,99.5 \%$ purity), PVC stabilizer LGP 8008 (diatomic lead phosphite content $10 \%-30 \%$, tribasic lead sulphate content 30\%-60\%, lead stearate diatomic content $10 \%-30 \%$ ), zinc stearate ( $\mathrm{Zn}$ content $11 \%$, melting point $127^{\circ} \mathrm{C}$ ), and antioxidant Uvinul $5050 \mathrm{H}$ (density $0.99 \mathrm{~g} / \mathrm{cm}^{3}$, melting temperature range $95-125^{\circ} \mathrm{C}$, heat stability higher than $\left.300^{\circ} \mathrm{C}, \mathrm{pH} 7\right)$, (2) vulcanized nitrile rubber powder obtained by buffing the rubberized metallic rolls when correcting them. It was subjected to chemical tests and the results are shown in Table 1. Acetone extract value $(23.86 \%)$ reveals such matters as free sulphur, curing accelerators, antioxidants, resins, plasticizers, lubricants, and monomers being present in the elastomers. Ash value (19.61\%) reveals the presence of such fillers as metal oxides (zinc oxide), chalk precipitate, and other passive fillers. $\mathrm{HCl}$ insoluble matter value (8.85\%) reveals the active filler such as silica precipitate being present in the rubber blends used in preparing rubber waste powder [7].

2.1.1. Polymer Composites Preparation. Polymer composites were obtained in two stages: (1) PVC plasticizing and (2) preparing blends based on vulcanized nitrile rubber powder and plasticized PVC.

(1) PVC plasticizing was accomplished by plasticizer (DOP) absorption into PVC when mixing in a $2 \mathrm{~L}$ vessel of plasticorder PLV 330 Brabender at $70 \mathrm{rpm}$, temperature of $40^{\circ} \mathrm{C}$ for $10 \mathrm{~min}$. For a good thermal stability, temperature stabilizer and antioxidants have been introduced over time. The resulted plasticized PVC is processed into a sheet on a laboratory roll electrically heated, the resulted sheet being used in the next stage in the blend preparation.

(2) Preparing the experimental polymer composites based on plasticized PVC and NBR rubber powder on the laboratory electrically heated roller mill. Process variables were as follows: temperature: $140-170^{\circ} \mathrm{C}$, friction coefficient: $1: 1.24$. The ingredient addition sequence: plasticized PVC (7-15'), rubber powder (5$\left.10^{\prime}\right)$, homogenization, and removing from the roller mill $\left(3-5^{\prime}\right)$.

Table 2 presents the recipe of NBR rubber powder/PVC plasticizing blends.

The resulted polymer composites were granulated in a laboratory extruder granulator, equipped with a heating system (at $160-175^{\circ} \mathrm{C}$ ) in three stages, a granulating device, knives, and cooling system.

Test samples intended for the blend characterization were prepared both by compression molding into $2 \times 150 \times 150 \mathrm{~mm}$
TABLE 2: Formulations of the polymer composites based on plasticized PVC/vulcanized NBR rubber powder.

\begin{tabular}{lccc}
\hline Reference number & Ingredients/blends & C1 & C2 \\
\hline$[1]$ & NBR rubber powder, g & 75 & 135 \\
{$[2]$} & PVC, g & 150 & 150 \\
{$[3]$} & DOP, g & 75 & 75 \\
{$[4]$} & LGR 8008, g & 6 & 6 \\
{$[5]$} & Zinc stearate, g & 0.75 & 0.75 \\
{$[6]$} & Uvinul 5050, g & 1.5 & 1.5 \\
\hline
\end{tabular}

sheets on a laboratory vulcanizing press at a temperature of $160^{\circ} \mathrm{C}$ and pressure of $150 \mathrm{MPa}$ for 10 minutes and by injection in a two nest mold using an injection device at $165^{\circ} \mathrm{C}$ and $2^{\prime}$ cooling time. The molded samples were stored away from light, at room temperature.

2.1.2. Laboratory Tests. Mechanical properties of samples were measured on a Schopper tensile tester with a nominal rate of the traverse of the moving grip of $460 \mathrm{~mm} / \mathrm{min}$. Modulus at $100 \%$ strain, tensile strength, and elongation at break tests were carried out according to the conditions described in ISO 37/2012, on dumb-bell shaped specimens of type 2 (the precision and the uncertainties of the test are \pm 0.64 for tensile strength and \pm 2.95 for elongation at break). Tearing strength tests were carried out using angular test pieces (type II) according to SR EN 12771/2003. Hardness of materials was measured using the Shore A scale with samples of $6 \mathrm{~mm}$ thickness, by using a hardener tester according to ISO 7619$1 / 2011$ (the precision and the uncertainties of the test are $\pm 0.05)$. Elasticity was evaluated with a Schob test machine using $6 \mathrm{~mm}$ thick samples, according to ISO 4662/2009. Residual elongation is the elongation of a specimen measured 1 minute after rupture in a tensile test. It was calculated using the following formula:

$$
\text { Residual elongation }(\%)=\left[\frac{L-L_{0}}{L_{0}}\right] \times 100,
$$

where $L_{0}$ is the initial length between two marks and $L$ is the length between the marks 1 minute after the sample broke in a tensile test.

Accelerated ageing trial was done according to SR ISO $188 / 2007$ using the hot air circulation oven method. Similar samples to those used for tensile testing and for hardness determination were used. Test duration was of 7 days and temperature of $70 \pm 1^{\circ} \mathrm{C}$. The results were compared with those from samples not subjected to ageing.

The densities of elastomer samples were measured according to ISO 2781/2010 (the precision and the uncertainties of the test are \pm 0.09 ).

Determining abrasion resistance was done according to ISO 4649/2010, the cylinder method, using a pressure of $10 \mathrm{~N}$. Abrasion resistance was expressed by relative volume loss in relation to calibrated abrasive paper. A wearing tester with abrasive cloth and abrasive based on normal electrocorundum on dressed cloth substrate with granulation of 212-80 $\mu \mathrm{m}$ (PE 80), whose abrasiveness must be of 180$220 \mathrm{mg}$ control rubber. The samples used were obtained from 
TABle 3: Physical-mechanical characteristics for the polymer composites based on PVC plasticized/vulcanized NBR rubber powder.

\begin{tabular}{|c|c|c|c|c|c|c|c|}
\hline $\begin{array}{l}\text { Reference } \\
\text { number }\end{array}$ & Characteristics/blends & $\begin{array}{l}\text { The } \\
\text { uncertainties } \\
\text { of tests }\end{array}$ & $\begin{array}{l}\mathrm{C} 1 \text { compression } \\
\text { molded sample }\end{array}$ & $\begin{array}{l}\mathrm{C} 1 \text { injected } \\
\text { sample }\end{array}$ & $\begin{array}{c}\mathrm{C} 2 \\
\text { compression } \\
\text { molded sample }\end{array}$ & $\begin{array}{l}\text { C2 injected } \\
\text { sample }\end{array}$ & $\begin{array}{l}\text { Limits } \\
\text { according to } \\
\text { STAS } \\
10040-74 \\
\end{array}$ \\
\hline [1] & Hardness, ${ }^{\circ} \mathrm{Sh} \mathrm{A}$, & \pm 0.05 & 73 & 73 & 71 & 65 & $70 \pm 5$ \\
\hline [2] & Elasticity, \%, & & 7 & 8 & 8 & 10 & \\
\hline [3] & $100 \%$ modulus, $\mathrm{N} / \mathrm{mm}^{2}$ & & 5.1 & 4.1 & 3.8 & 2.7 & \\
\hline$[4]$ & Tensile strength, $\mathrm{N} / \mathrm{mm}^{2}$ & \pm 0.64 & 10.6 & 9.7 & 10.4 & 9.5 & Min. 6,37 \\
\hline [5] & Elongation at break, \% & \pm 2.95 & 300 & 300 & 393 & 420 & Min. 300 \\
\hline [6] & Residual elongation, \% & & 20 & 21 & 17 & 20 & \\
\hline [7] & Tear strength, $\mathrm{N} / \mathrm{mm}$ & & 56 & 50 & 40 & 46 & \\
\hline [8] & density, $\mathrm{g} / \mathrm{cm}^{3}$ & \pm 0.09 & 1.24 & 1.24 & 1.23 & 1.22 & \\
\hline [9] & Resistance to abrasion, $\mathrm{mm}^{3}$ & \pm 0.15 & 141 & 139 & 139 & 134 & \\
\hline$[10]$ & $\begin{array}{c}\text { Ozone resistance for } 100 \mathrm{~h} \text {, } \\
30^{\circ} \mathrm{C}, 200 \mathrm{pphm} \text { ozone } \\
\text { concentration and a } 20 \% \\
\text { tension }\end{array}$ & & $\begin{array}{l}\text { No visible } \\
\text { cracks under a } \\
2 \mathrm{X} \\
\text { magnification }\end{array}$ & $\begin{array}{l}\text { No visible } \\
\text { cracks under a } \\
2 \mathrm{X} \\
\text { magnification }\end{array}$ & $\begin{array}{l}\text { No visible } \\
\text { cracks under a } \\
2 \mathrm{X} \\
\text { magnification }\end{array}$ & $\begin{array}{l}\text { No visible } \\
\text { cracks under a } \\
2 \mathrm{X} \\
\text { magnification }\end{array}$ & $\begin{array}{c}\text { No visible } \\
\text { cracks under } \\
\text { a } 2 \mathrm{X} \\
\text { magnification }\end{array}$ \\
\hline
\end{tabular}

rolled blends and pressed by cutting with a rotating die and have cylindrical shape, with a diameter of $16 \mathrm{~mm}$ and height of min. $6 \mathrm{~mm}$. The precision and the uncertainties of the test are \pm 0.15 .

Flexion resistance (Ross Flex) was determined according to SR 7645/1994. Samples were obtained by punching rubber plates and have rectangular shape. The trial was performed using a Ross Flex device, monitoring crack marks on each sample at intervals of $1 \mathrm{~h}, 2 \mathrm{~h}, 4 \mathrm{~h}, 8 \mathrm{~h}, 24 \mathrm{~h}, 48 \mathrm{~h}, 72 \mathrm{~h}$, and $96 \mathrm{~h}$. The precision and the uncertainties of the test are \pm 300 .

Resistance to swelling by liquids was determined according to ISO $1817 / 2005$ by the change in mass and volume using the following method: the test pieces of known weight $\left(W_{1}\right)$ and volume $\left(V_{1}\right)$ were immersed in various solvents: water, sun flower oil, soya oil, animal fat, sulfuric acid $70 \%$, nitric acid $50 \%$, caustic soda $50 \%$, isooctane, toluene, $70 \%$ isooctane, and $30 \%$ toluene solution, in diffusion test bottles and kept at room temperature for $22 \mathrm{~h}$. After immersion, the samples were taken out from the solvents, and the wet surfaces were quickly dried using a tissue paper and reweighted $\left(W_{2}\right)$, respectively, $\left(V_{2}\right)$. Swelling index (\%) was calculated by the following equation:

$$
\begin{aligned}
& \text { change in weigh }=\frac{\left[\left(W_{2}-W_{1}\right) \times 100\right]}{W_{1}}, \\
& \text { change in volume }=\frac{\left[\left(V_{2}-V_{1}\right) \times 100\right]}{V_{1}} .
\end{aligned}
$$

The precision and the uncertainties of the test are \pm 0.04 .

Ozone resistance was determined using a MAST-700-1 device according to SR ISO 1431-1/2002.

For rubber powder, determine the ash in accordance with method a of ISO 247:2006 and determine the acetone extract in accordance with method a of ISO 1407:2011.

All measurements were taken several times and the result values were averaged on three to five measurements.

\section{Results and Discussions}

In Table 3, the characteristics of the PVC/vulcanized NBR rubber powder composites are shown determined on injected and compression molded samples.

The data in Table 3 show that the values for physical mechanical characteristics for compression molded samples, and injected samples are similar excepting: (1) a slight decrease of elasticity, (2) a slight decrease of tensile strength and $100 \%$ modulus, and (3) a decrease for hardness for C2 from 71 to $65 \mathrm{ShA}$. The values are in the limits of STAS 1004074 for irrigation flexible pipes.

The increase of rubber powder quantity leads to an increase of hardness, $100 \%$ modulus, tear strength, and a decrease of elongation at break. Similar modification of characteristics due to the increase of rubber powder quantity was determined also by other researchers [2, 12-14].

$\mathrm{C} 1$ composite was selected for the production of irrigation hose, and further characterization was conducted in order to determine other fields of use.

The results (Table 4 ) prove that the new polymer composites have a good behavior for accelerated aging (a decrease of hardness of only $1^{\circ} \mathrm{ShA}$ and elongation at break and tearing resistance variation is under 5\%), behave well on repeated flexions at room temperature and at low temperature $\left(-20^{\circ} \mathrm{C}\right)$, and are resistant to water, concentrated acids and basis, animal fat, soya and sun flower oil, isooctane, and low resistance to toluene and toluene isooctane solution. According to the physical mechanical properties (Tables 3 and 4), the following fields of use were chosen: gaskets (extruded gaskets, general use gaskets excepting oil industry), rubber items for the automotive industry (rubber mats, seals), hoses and rubber pipes (rubber pipes for mud draining, for heating railroad cars, suction hoses, oxygen and acetylene welding hose, hoses for mobile irrigation systems, hoses for acid or basic solutions, etc.), rubber footwear, and rubber protection equipment (water and fat resistant boots), and so forth. 
TABle 4: Physical-mechanical characteristics for the selected polymer composites.

\begin{tabular}{|c|c|c|c|c|}
\hline $\begin{array}{l}\text { Reference } \\
\text { number }\end{array}$ & Characteristics & $\mathrm{UM}$ & The uncertainties of tests & Value \\
\hline \multirow{8}{*}[1]{} & Properties after accelerated ageing $70^{\circ} \mathrm{C} \times 168 \mathrm{~h}$ & & & \\
\hline & Hardness, ${ }^{\circ} \mathrm{ShA}$ & ${ }^{\circ} \mathrm{ShA}$ & \pm 0.05 & 75 \\
\hline & Elasticity, \%, & $\%$ & & 9 \\
\hline & $100 \%$ modulus, $\mathrm{N} / \mathrm{mm}^{2}$ & $\mathrm{~N} / \mathrm{mm}^{2}$ & & 4,9 \\
\hline & Tensile strength, $\mathrm{N} / \mathrm{mm}^{2}$ & $\mathrm{~N} / \mathrm{mm}^{2}$ & \pm 0.64 & 9,5 \\
\hline & Elongation at break, \% & $\%$ & \pm 2.95 & 333 \\
\hline & Residual elongation, \% & $\%$ & & 20 \\
\hline & Tear strength, $\mathrm{N} / \mathrm{mm}$ & $\mathrm{N} / \mathrm{mm}$ & & 52,5 \\
\hline \multirow{3}{*}[2]{} & Ross Flex flexions at $23^{\circ} \mathrm{C}$ (no. of cycles) & & \pm 300 & \\
\hline & (i) $\mathrm{la}-20^{\circ} \mathrm{C}$ & Flexions & & 216000 \\
\hline & (ii) $1 \mathrm{la}+23^{\circ} \mathrm{C}$ & Flexions & & $>150000$ \\
\hline \multirow{34}{*}{ [3] } & Determination of resistance to liquids & & \pm 0.04 & \\
\hline & Water $20^{\circ} \mathrm{C}, 22 \mathrm{~h}$ & & & \\
\hline & (i) Change in mass & $\%$ & & 0 \\
\hline & (ii) Change in volume & $\%$ & & $-0,8$ \\
\hline & Water $70^{\circ} \mathrm{C}, 22 \mathrm{~h}$ & & & \\
\hline & (i) Change in mass & $\%$ & & $-1,04$ \\
\hline & (ii) Change in volume & $\%$ & & $-0,61$ \\
\hline & Sulfuric acid $\left(\mathrm{H}_{2} \mathrm{SO}_{4}\right) 70 \%$ & & & \\
\hline & (i) Change in mass & $\%$ & & 0,29 \\
\hline & (ii) Change in volume & $\%$ & & $-0,55$ \\
\hline & Nitric acid $\left(\mathrm{HNO}_{3}\right) 50 \%$ & & & \\
\hline & (i) Change in mass & $\%$ & & 4,7 \\
\hline & (ii) Change in volume & $\%$ & & 2,8 \\
\hline & Caustic soda $(\mathrm{NaOH}) 50 \%$ & & & \\
\hline & (i) Change in mass & $\%$ & & 0,24 \\
\hline & (ii) Change in volume & $\%$ & & $-0,21$ \\
\hline & Sun flower oil & & & \\
\hline & (i) Change in mass & $\%$ & & $-0,3$ \\
\hline & (ii) Change in volume & $\%$ & & $-0,56$ \\
\hline & Soya oil & & & \\
\hline & (i) Change in mass & $\%$ & & 0,82 \\
\hline & (ii) Change in volume & $\%$ & & 1,23 \\
\hline & Animal fat & & & \\
\hline & (i) Change in mass & $\%$ & & 0,65 \\
\hline & (ii) Change in volume & $\%$ & & 1,16 \\
\hline & Toluene & & & \\
\hline & (i) Change in mass & $\%$ & & 64,6 \\
\hline & (ii) Change in volume & $\%$ & & 94,6 \\
\hline & Isooctane & & & \\
\hline & (i) Change in mass & $\%$ & & 0 \\
\hline & (ii) Change in volume & $\%$ & & 1,12 \\
\hline & $70 \%$ isooctane and $30 \%$ toluene solution & & & \\
\hline & (i) Change in mass & $\%$ & & 12,8 \\
\hline & (ii) Change in volume & $\%$ & & 22 \\
\hline
\end{tabular}

\section{Conclusions}

Blending vulcanized nitrile rubber waste powder with plasticized PVC was obtained blends low hardness, high elongation at break, and high tensile strength. Two kinds of composites were produced and characterized in order to select the most suitable for irrigation pipes production. The results show for the selected polymer composites a good behavior to 
accelerated aging, to repeated flexions at room temperature and low temperature $\left(-20^{\circ} \mathrm{C}\right)$, a very good resistance to water, acids and basis, animal fat, sun flower oil, and isooctane. According to these properties the selected blend is suitable to the next fields of use: gaskets, rubber hoses and pipes, rubber footwear, rubber protection equipment.

The resulted polymer composites can be used in the manufacture of a large range of products, like hoses, gaskets, shoe heels, joint packs, slab pavements in sport halls, and so forth, with competitive characteristics as compared to the similar products from virgin materials $[4,5,7]$.

This is an efficient procedure for rubber waste reclamation as a result of polymer composites employed as substitutes for thermoplastics-thus resulting in material savings, rubber waste recycling, no wastes resulted from polymer composite processing, as the fleshes and refuses can be recycled. These composites can be processed by some techniques similar to those for plastics and rubber blends (pressing, injection, extrusion, etc.) $[5,6]$.

\section{References}

[1] M. Tipanna and D. D. Kale, "Composites of waste, ground rubber particles and poly(vinyl chloride)," Rubber Chemistry and Technology, vol. 70, no. 5, pp. 815-819, 1997.

[2] G. P. Goncharuk, M. I. Knunyants, O. A. Serenko, and A. N. Kryuchkov, "Mechanical properties of modified thermoplastic elastomers based on low-density polyethylene and rubber powder," Polymer Recycling, vol. 5, no. 3, pp. 161-164, 2000.

[3] D. Zuga and C. Cincu, "Polymer composites by reclaiming rubber wastes resulting from finishing the rubberized rolls used in printing industry," UPB Scientific Bulletin Series B, vol. 68, no. 1, pp. 25-30, 2006.

[4] D. Zuga and C. Cincu, "Use of cured butadiene styrene rubber powder in preparing polymer composites," Leather and Footwear Journal, vol. 3, pp. 22-26, 2005.

[5] M. D. Zuga, C. Cincu, and L. Alexandrescu, "Polymer composites based on rubber powder and low density polyethylene," Leather and Footwear Journal, vol. 5, no. 1, pp. 14-17, 2005.

[6] Y. A. Vetkin, G. M. Goncharow, and M. O. Shilov, "Reological properties of polyetylene based composites containing rubber crumbs," International Polymer Science and Technology, vol. 25, no. 12, pp. 79-80, 1998.

[7] D. Zuga, V. Bratulescu, C. Gaidau, and C. Cincu, "Use of nitrile rubber wastes in making fatty matter-resistant boots, III IC Light Industry-fibrous materials," in Proceedings of the International Scientific Conference on Light Industry-Fibrous Materials, K. Smiechowski, Ed., pp. 156-161, Radom, 2005.

[8] W. V. Titow, PVC Technology, ch 2, Elsevier Applied Science Publishers, 4th edition, 1984.

[9] D. Braun and E. Bezdadea, "Encyclopedia of PVC," L. I. Nass and C. A. Heiberger, Eds., Ch 1, 1986.

[10] V. L. D. C. Lapa, L. L. Y. Visconte, J. E. D. S. Affonso, and R. C. R. Nunes, "Aluminum hydroxide and carbon black filled NBR/ PVC composites-vulcanization and processability studies," Polymer Testing, vol. 21, no. 4, pp. 443-447, 2002.

[11] J. Thormer, H. Bertram, O. Benn, and H. Hurrnik, "Use of zinc salts of mercaptobenzimid azole and dithiophosphoric acid esters for the preparation on nitrile rubber/poly(vinyl chloride) mixture," U.S. Patent, no. 4, pp. 435-532, 1984.
[12] J. I. Kim, S. H. Ryu, and Y. W. Chang, "Mechanical and dynamic mechanical properties of waste rubber powder/HDPE composite," Journal of Applied Polymer Science, vol. 77, pp. 2595-2602, 2000.

[13] O. A. Serenko, G. P. Goncharuk, M. Y. Vdovin, and A. N. Kryuchkov, "Influence of injection moulding parameters on the properties of rubber-plastic composites," International Polymer Science and Technology, vol. 25, no. 10, pp. 54-57, 1998.

[14] M. D. Zuga and M. D. Berechet, "Polymeric composites based on rubber powder obtained from vulcanized rubber wastes and low density polyethylene," in Proceedings of the The 18th Session of Scientific Communications of "Petru Poni" Molecular Chemistry Institute, Progresses in the Science of Organic and Macromolecular Compounds, Iasi Academy, Iaşi, Romania, October 2004. 

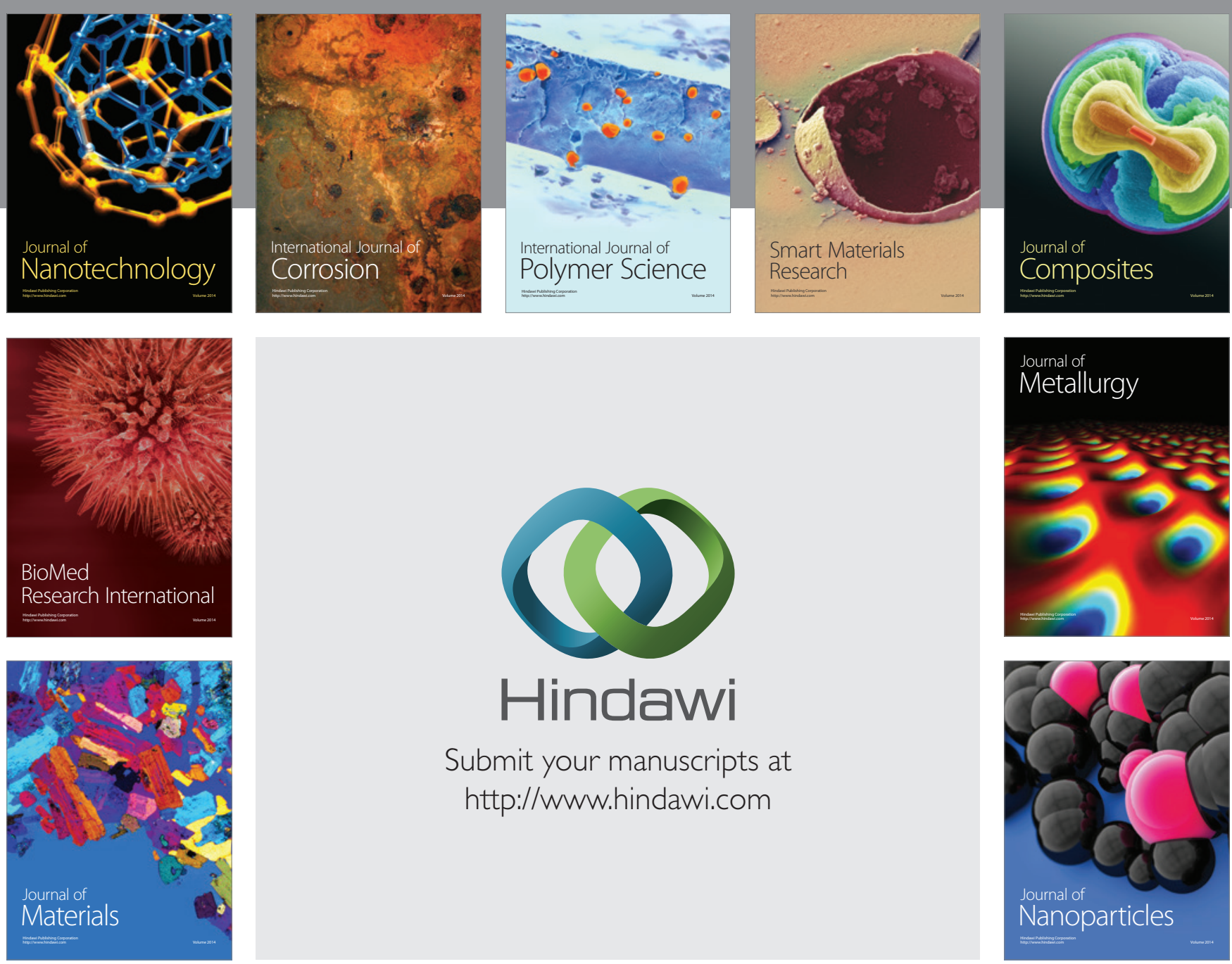

Submit your manuscripts at http://www.hindawi.com
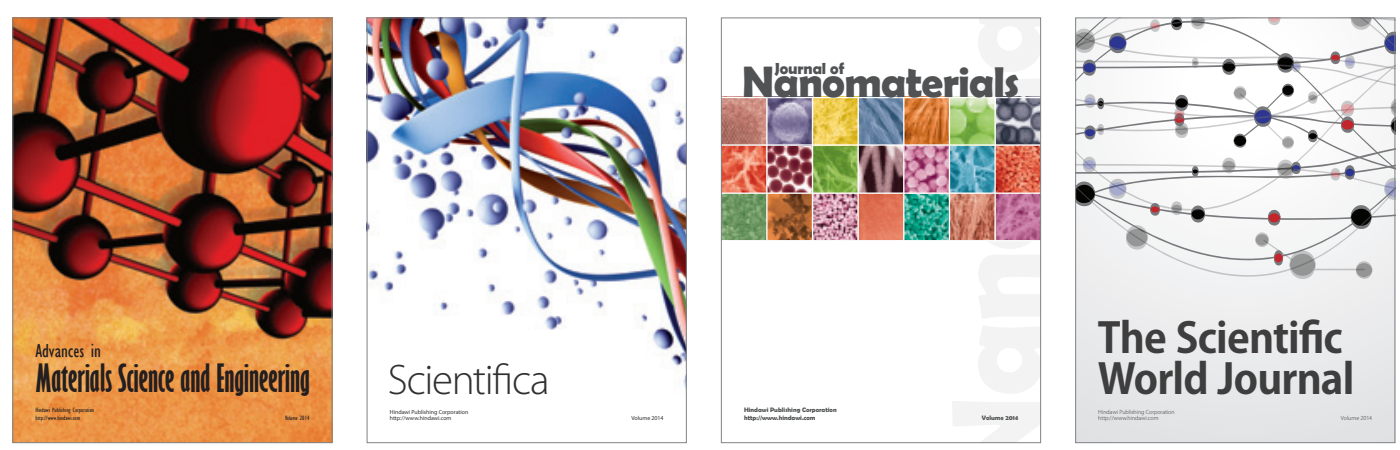

\section{The Scientific World Journal}
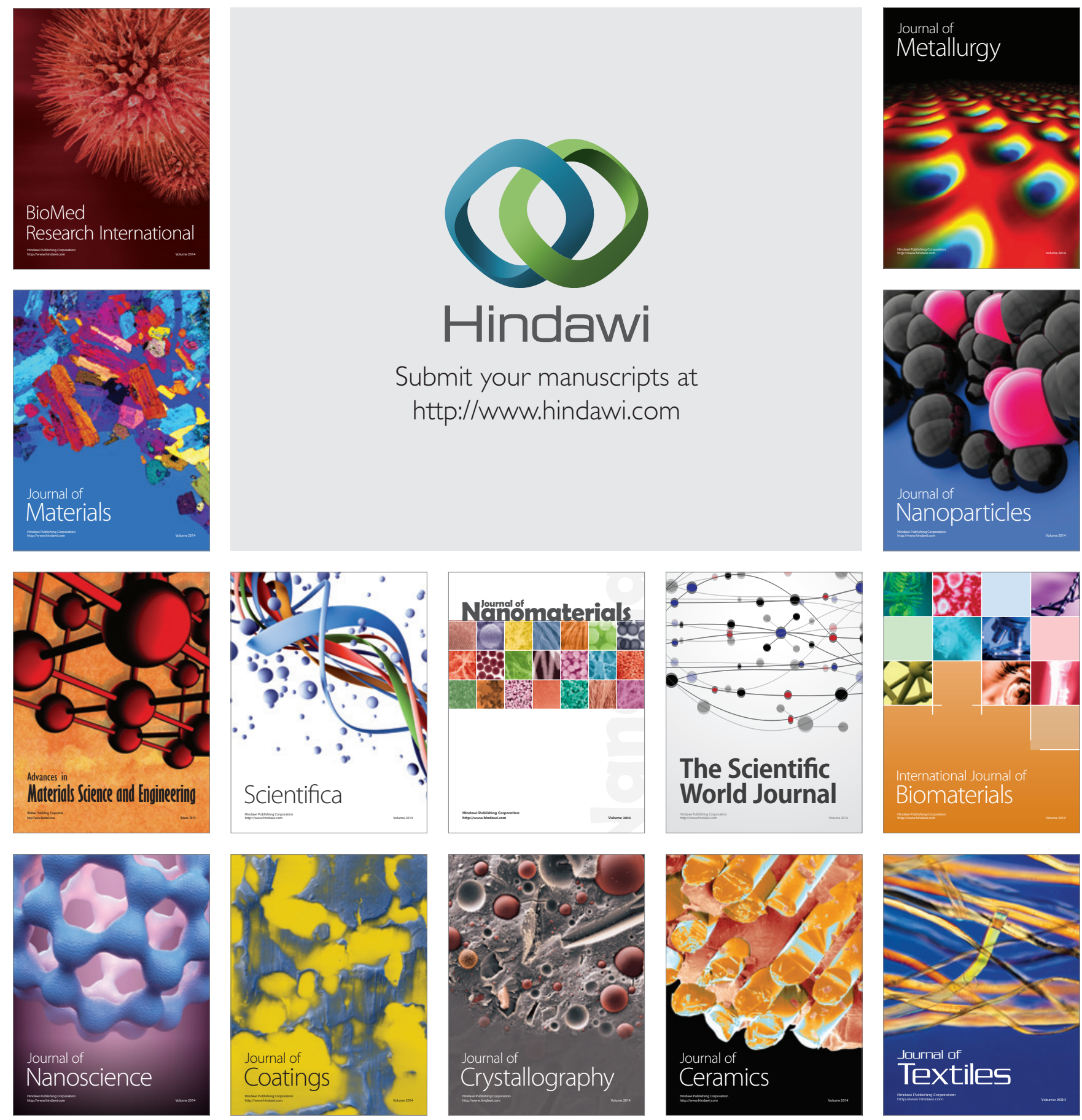